The 3rd International Conference on Biological Science 2013

(The 3rd ICBS-2013)

\title{
THE BIRD SPECIES IN YOGYAKARTA CITY: DIVERSITY, GUILD TYPE COMPOSITION AND NEST
}

\author{
Suripto, B.A. , H.S. Surakhman, Setiawan and J. Al Muthiya \\ Faculty of Biology, University of Gadjah Mada \\ suriptobambang@yahoo.com
}

\begin{abstract}
Ornitholog past studies focused on the natural environment, now they have a lot of studying birds in urban areas. In Java inhabited by 368 species of birds recorded settler and nomad 126 species of birds, but it is not known how many types of them which now lives in urban areas. Bird diversity in the city of Yogyakarta, which was founded in 1755 and now has a population of 388627 inhabitants, is unknown. The research objective was to determine the diversity, the proportion of community based on the type of bird feed (guild) and bird species nest in the city of Yogyakarta. The study was conducted during the day in April-May 2013 in the 7 villages of 3 subdistricts in the city center Kraton, Gondomanan and Ngampilan. Data colection used Point of Abundance Index method, and analyzed by the Shannon Diversity Index - Wienner ; types of feed directly observed and are determined based on a review of literature and the proportion of bird communities based on guild were analyzed with the use of modified importance value index; nest observed directly and analyzed descriptively. The results showed in Yogyakarta were found 28 species of birds covered in 11 familia with moderate levels of diversity (diversity index 2.2) and 5 types including protected status that is Anthresep malacensis, Nectarinia jugularis and Arachnothera Iongirostra (Fam.Nectariniidae), Alcedo atthis and Halcyon cyanoventris (Fam. Alcedinidae). Composition based on the guild type is graminivorous (46.58\%), nectarivorous ( $46.51 \%)$, nectrivoous (5.53\%), frugivorous ( $1.08 \%$ ), and $0.29 \%$ piscivorous, and was found at least nine species of birds that nest in the city of Yogyakarta. Therefore, birds in the city of Yogyakarta is quite diverse and populated several protected species, it is necessary to research on biological properties, especially the origins, patterns of reproduction and structural adaptation and behavior.
\end{abstract}

Keywords : City of Yogyakarta, birds, diversity index, type of feed, nest

\section{INTRODUCTION}

In general, the development of human civilization has caused negative impacts on biodiversity, however, many animals appeared to have adapted to environmental stresses created by human civilization. The pressure of the urban environment as a source of food, predators and other threats apparently some kind of animal can grow quickly at close to human existence. Success they thrive in an urban environment has prompted many researchers to conduct studies various aspects of life and even the results of many studies that reveal valuable new information related to the process of evolution and selection process . Therefore adaptation in urban bird runs fast, then it is a laboratory for the study of natural selection. The study of urban birds is very important to know the ecological aspects such as how they obtain food and shelter, and find out the process of natural selection that may be in action.

Ornitholog past studies focused on the natural environment, but now days they have a lot of studying birds in urban areas. In Java inhabited by 368 species of birds recorded settler and nomad 126 species of birds (MacKinnon et al., 2010), but it is not known how many species of them which now lives in urban areas. Based on observations made Ontario et al. (1990), variations in the composition of bird species can differ between one city to another, according to the ability of each city in support of bird life as well as the history of the spread

ISSN 2413-0877 @ 2015 The Authors.

Published by KnowledgeE Publishing Services This is an open access article under the CC BY-NC-ND license (http://creativecommons.org/licenses/by-nc-nd/4.0)

Selection and Peer-review under responsibility of the 3rd ICBS-2013

Doi http://dx.doi.org/10.18502/kls.v2i1.141 
of bird in the city. The existence of community centers in the city can affect the existence of the bird. Urban bird prefers a location away from the center of the crowd. Bird study conducted in urea fertilizer factory PT Kujang shows that the number of bird species and individuals increased with increasing distance from the center of industrial activity (Hernowo and Prasetyo, 1989). City changes can not be avoided. Not only humans who must adapt to these changes, so do the birds. In order to survive, birds have to adapt that of course takes time and has to change his behavior patterns ranging from the behavior of nesting, foraging, to recognize new types of threats that had not previously been encountered .

Yogyakarta city was built in 1755, along with the construction of the Kingdom Ngayogyakarta Hadiningrat by Sri Sultan Hamengku Buwono I at Banyan Forest, an area between the river Code and the river Winongo where the location is visible in terms of defense strategy at that time. Before the Palace was finished, Sri Sultan Hamengku Buwono design guest house which occupies Ambarketawang Limestone area, from where he is always supervise and manage the construction of the palace that is being done. A year later the lane I deign to enter the inaugural New Castle. Thus stood the city of Yogyakarta or with his whole name is Negari Ngayogyakarta. Houses Ambarketawang abandoned by the lane to move to settle in the new palace. Inauguration of which occurred Date October 7, 1756. Now part of the city of Yogyakarta at the center of the city is included in the subdistrict administrative Kraton, and Subdistrict Gondomanan and Ngampilan in the northern part of Yogyakarta Palace. So far studies have not been conducted on birds in urban areas of Yogyakarta is now increasingly populated. The purpose of research is to study the diversity, bird species composition based on guild type, and the types of birds that nest in the city of Yogyakarta, Yogyakarta Special Province.

\section{METHODS AND MATERIALS}

\section{Location and Time Research}

Place the conduct of research is in the Subdistrict Kraton, Gondomanan, and Ngampilan, Yogyakarta City. The study began on 5 April to 11 May 2013. Observations made at 07:00 to 10:00 and from 15:00 to 17:00 .

\section{Equipment and Materials}

Tools and materials used include: binoculars to be used for bird watching , bird species guide book that will help in identifying birds observed, GPS, map of the area which is used to determine the coordinates of the location of data collection, a camera that will be used to documenting activities, and take pictures of birds observed, and the latter is stationery to record the results of data retrieval .

Preliminary investigation involves determining the location of the study by using a map scale of $1: 10,000$. The site covers the Subdistrict Gondomanan (Village Ngupasan and Prawirodirjan), Kraton District (Village Patehan, Panembahan and Duchy ) and the District Ngampilan (Village Ngampilan and Notoprajan) and in each village selected three zones namely Zone A : plant abundance; Zone B : plants moderat, and Zone C : plants rare. Each study site will be marked to facilitate the process of observation. 
Bird community surveys conducted by the point count method (Point Count) (Bibby et al., 2000) were modified. At the point count method (Point count) data recorded includes names of bird species encountered by the specified time interval ( 15 minutes). In one sample point at each study site contained 10 point count observations that the distance between the point of observation is more than $100 \mathrm{~m}$ to reduce the possibility of individual birds were observed more than once. Assumptions visibility towards the subject is $30 \mathrm{~m}$. Bird watching is done by using a binocular or camera. Bird identification is done by morphological observation, sound, and with field guides (MacKinnon et al., 2010). Protection status of each species encountered in the study area is determined by PP N0 7, 1999 on the Preservation of Fauna and Flora, the existence of migratory bird species based on literature review (MacKinnon et al., 2010), and other protection status under the provisions of the IUCN.

Species diversity was measured using the Shannon-Wienner Diversity Index (Odum, 1971). Interpretation of results Shannon-Wienner Index Diversity of bird species are : > 3 (high diversity, spread the number of individuals of each species of bird communities high and high stability; 1.5 to 3 (moderate diversity, spread the number of individuals of each species of bird being and stability of the community are $;<1.5$ ( low diversity, the spread of the low number of individuals of each species of bird communities and low stability). Bird species composition based on patterns determined by adding up the amount of feed Importance Value Index ( IVI ) similarity of the pattern of each type of feed the birds that were found in each study site , where : inp = relative density + relative frequency (Odum, 1971). Bird guild type (feeding patterns) are determined based on literature review (MacKinnon et al., 2010). The types of birds that nest in the study area are directly observed and analyzed descriptively .

\section{RESULT AND DISCUSSION}

\section{Diversity of bird species in Yogyakarta City}

Table 1 shows that in the city of Yogyakarta at least 28 species of birds found include 11 familia including and 5 species of protected birds i.e. Anthresep malacensis, Nectarinia jugularis and Arachnothera longirostra (Fam.Nectarinidae), Alcedo atthis and Halcyon cyanoventris (Fam. Alcedinidae). Pictures of some of bird species found in Yogyakarta City are presented in Figure 1 to 8 . Shannon-Wienner diversity index is 2.2 or moderate diversity. However, it turns out when the diversity index was calculated for each zone (Zone A : plant abundance; Zone $\mathrm{B}$ : plants moderat, and Zone $\mathrm{C}$ : plants rare) the result is relatively

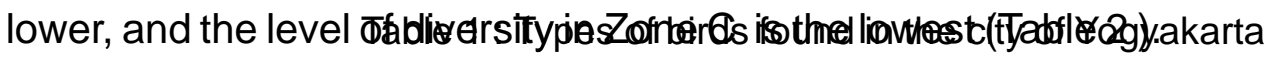

\begin{tabular}{|c|c|c|c|c|c|c|c|}
\hline \multicolumn{4}{|c|}{ Bird Species } & \multicolumn{3}{|c|}{ Subdistrict } & \multirow{2}{*}{$\begin{array}{c}\text { Consevation } \\
\text { Status }\end{array}$} \\
\hline No & English Name & Familia & Scientific Named & $\begin{array}{l}\text { Gondo- } \\
\text { manan }\end{array}$ & $\begin{array}{l}\text { Kra- } \\
\text { ton }\end{array}$ & $\begin{array}{l}\text { Ngam- } \\
\text { pilan }\end{array}$ & \\
\hline 1 & $\begin{array}{l}\text { Pink-necked Green- } \\
\text { Pigeon }\end{array}$ & & Treron vernans & V & V & - & \\
\hline 2 & $\begin{array}{l}\text { Large Green-Pigeon } \\
\text { Besar }\end{array}$ & & Treron cappelei & V & - & - & \\
\hline 3 & Island Collard-Dove & Columbidae & Streptopelia bitorquata & v & V & - & \\
\hline 4 & Spotted-Dove & & Streptopelia chinensis & v & v & v & \\
\hline 5 & Emerlad Dove & & Chalcophaps indica & v & - & - & \\
\hline 6 & ZebraDove & & Geopelia striata & - & $\mathrm{v}$ & - & \\
\hline
\end{tabular}




\begin{tabular}{|c|c|c|c|c|c|c|c|}
\hline \multicolumn{4}{|c|}{ Bird Species } & \multicolumn{3}{|c|}{ Subdistrict } & \multirow{2}{*}{$\begin{array}{c}\text { Consevation } \\
\text { Status }\end{array}$} \\
\hline No & English Name & Familia & Scientific Named & $\begin{array}{l}\text { Gondo- } \\
\text { manan }\end{array}$ & $\begin{array}{l}\text { Kra- } \\
\text { ton }\end{array}$ & $\begin{array}{l}\text { Ngam- } \\
\text { pilan }\end{array}$ & \\
\hline 7 & Glossy Swiftlet & \multirow{2}{*}{ Apodidae } & Collocalia esculenta & V & V & V & \\
\hline 8 & Cave-Swiftlet & & Collocalia linchi & - & V & - & \\
\hline 9 & Sooty-headed Bulbul & \multirow{2}{*}{ Pycnonotidae } & Pycnonotus aurigaster & V & V & V & \\
\hline 10 & Yellow-vented Bulbul & & Pycnonotus goiavier & V & V & V & \\
\hline 11 & Ashy Tailorbird & \multirow{4}{*}{ Silviidae } & Orthotomus ruficeps & V & V & V & \\
\hline 12 & Common Tailorbird & & Orthotomus sutorius & V & - & V & \\
\hline 13 & Mountain Tailorbird & & Orthotomus cucullatuss & - & V & - & \\
\hline 14 & Mueller'sBush Wabler & & Cettia vulcania & - & V & - & \\
\hline 15 & Red-tailed Fantail & Muscicapidae & Rhipidura phoenicura & - & V & - & \\
\hline 16 & $\begin{array}{l}\text { Brown-throated } \\
\text { Sunbird }\end{array}$ & \multirow{3}{*}{ Nectariniidae } & Anthreptes malacensis & V & V & V & Protected \\
\hline 17 & Olive-backed Bird & & Nectarinia jugularis & V & - & V & Protected \\
\hline 18 & Little Spiderhunter & & Arachnothera longirostra & - & - & V & Protected \\
\hline 19 & $\begin{array}{l}\text { Scarlet-headed } \\
\text { Flowerpecker }\end{array}$ & Dicaeidae & Dicaeum trochileum & V & V & - & \\
\hline 20 & Oriental White-eye & \multirow{2}{*}{ Zosteropidae } & Zosterops palpebrosus & V & V & V & \\
\hline 21 & Javan White-eye & & Zosterops flavus & V & V & V & \\
\hline 22 & Javan Munia & \multirow{4}{*}{ Ploceidae } & Lonchura leucogastroides & V & V & V & \\
\hline 23 & Scaly-breasted M unia & & Lonchura punctulata & V & - & V & \\
\hline 24 & White-headed Munia & & Lonchura maja & V & V & V & \\
\hline 25 & Eurasian Tree Sparrow & & Passer montanus & V & V & V & \\
\hline 26 & White-vented Myna & Sturnidae & Acridotheres javanicus & $\mathrm{V}$ & - & - & \\
\hline 27 & Common Kingfisher & \multirow{2}{*}{ Alcedinidae } & Alcedo atthis & - & - & $\mathbf{V}$ & Protected \\
\hline 28 & Javan Kingfisher & & Halcyon cyanovenris & - & - & $\mathbf{v}$ & Protected \\
\hline
\end{tabular}

Notes: Zone A : plant abundance; Zone B : plants moderat, and Zone C : plants rare

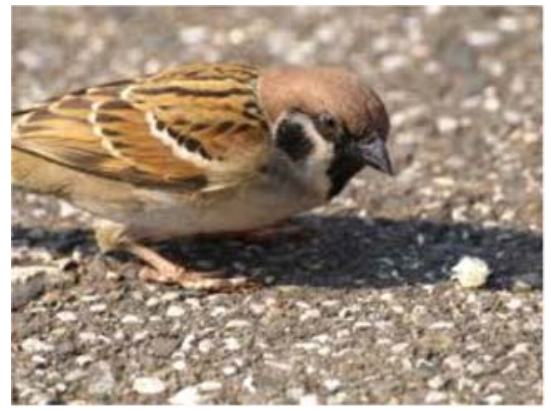

Figure 1: Eurasian Tree Sparrow (Passer montanus) (by Sigit, 2013)

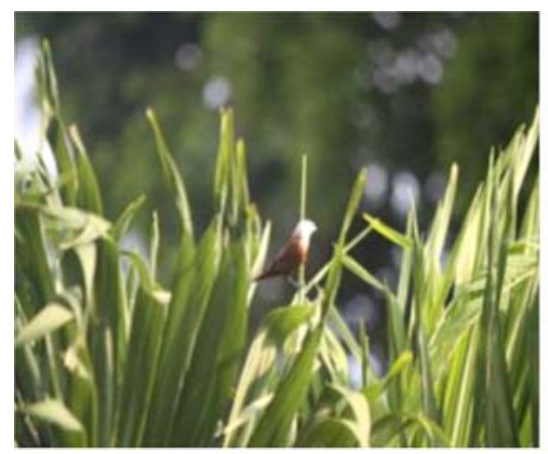

Figure 3: White-headed Munia (Lonchura maja)( by Sigit, 2013)

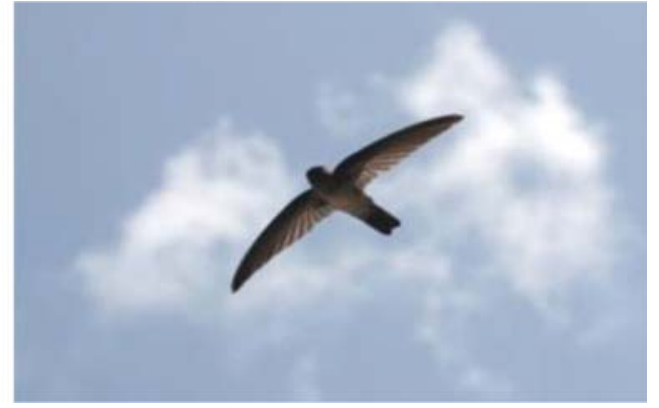

Figure 2: Glossy Swiftlet (Collocalia esculenta) (by Sigit, 2013)

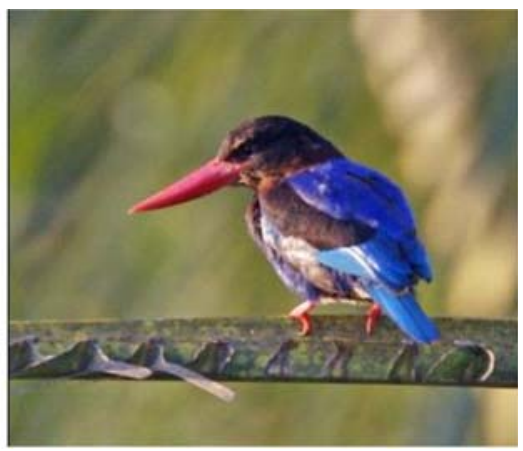

Figure 4: Javan Kingfisher (Halcyon cyanoventris) (by Sigit, 2013) 


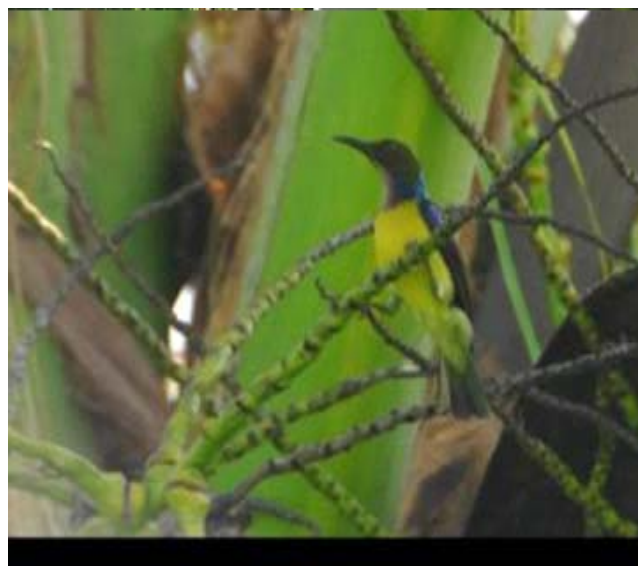

Figure 5: Brown-throated Sunbird (Anthreptes malacensis)) by Sigit, 2013)

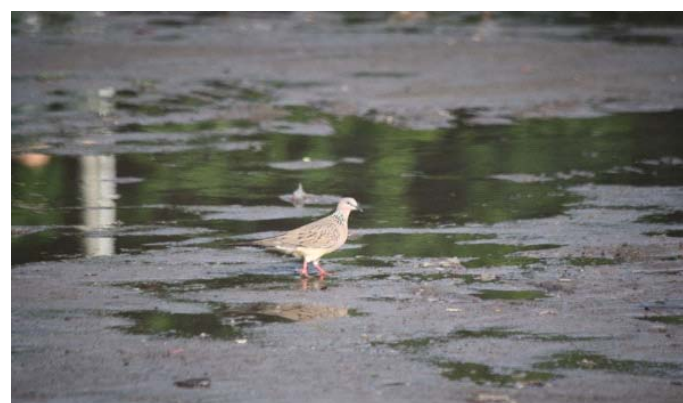

Figure 7: Spotted-Dove (Streptopelia chinensis) (By Surakhman, 2013)

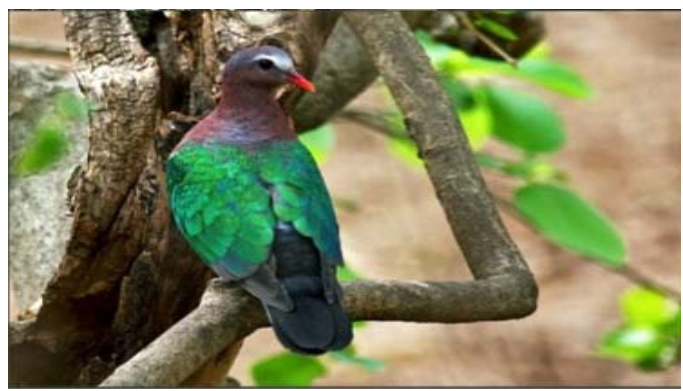

Figure 9: Emerlad Dove (Chalcophaps indica) (By Surakhman, 2013)

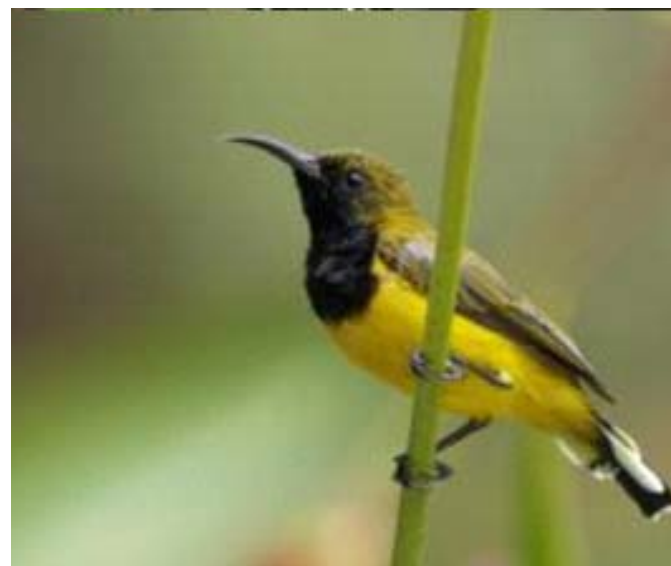

Figure 6: Olive-backed Bird (Nectarinia jugularis) (by Sigit, 2013)

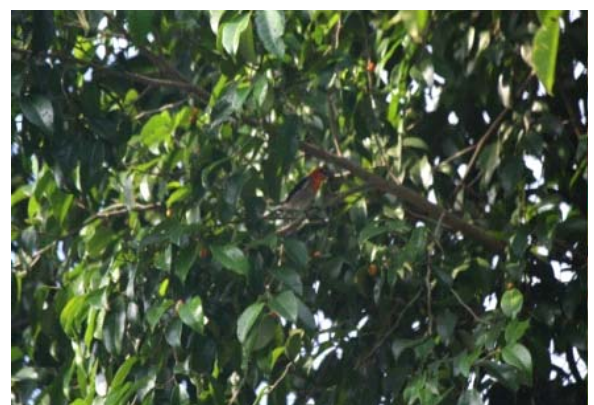

Figure 8: Scarlet-headed Flowerpecker (Dicaeum trochileum (By Surakhman, 2013)

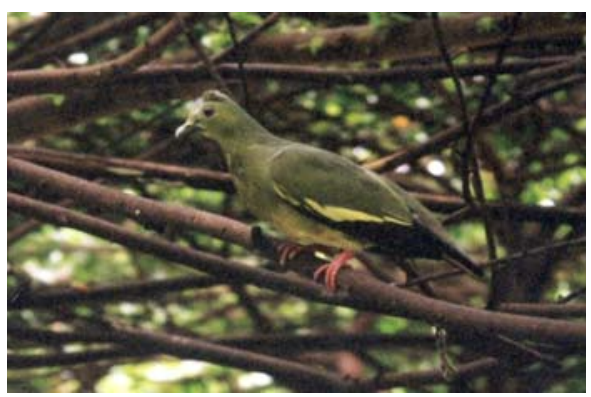

Figure 10: Large Green-Pigeon Besar (Treron cappelei) (By Surakhman, 2013)

Tabel 2: Diversity Index of bird species in each zones in Yogyakarta City

\begin{tabular}{llllll}
\hline \multirow{2}{*}{ No. } & \multirow{2}{*}{ Subdistrict } & Village & \multicolumn{3}{c}{ Zone } \\
\cline { 3 - 5 } & & & $\mathrm{A}$ & $\mathrm{B}$ & $\mathrm{C}$ \\
\hline \multirow{2}{*}{1} & \multirow{2}{*}{ Gondomanan } & Ngupasan & 2,112 & 1,479 & 0,842 \\
& & Prawirodirjan & 1,384 & 1,885 & 1,195 \\
\multirow{2}{*}{2.} & \multirow{2}{*}{ Kraton } & Patehan & 1,45 & 1,276 & 1,137 \\
& & Panembahan & 1,577 & 1,363 & 0,977 \\
\multirow{2}{*}{3.} & Kadipaten & 1,265 & 1,111 & 1,02 \\
& \multirow{2}{*}{ Ngampilan } & Ngampilan & 1,922 & 1,913 & 1,211 \\
& & Notoprajan & 1,572 & 1,442 & 1,500 \\
\hline
\end{tabular}

Note: Zone A : plant abundance; Zone B : plants moderat, and Zone C : plants rare 


\section{Bird species composition in Yogyakarta based on guild type}

Based on the pattern of feed (guild type), species of birds in the city of Yogyakarta include graminivorus, insectivorous, piscivorous, nectarivorous and frugivorous. The composition is the most graminivorous and insectivorous (Table 3).

Table 3: Composition of bird species in the city of Yogyakarta based on guild type

\begin{tabular}{llcccc}
\hline No. & \multirow{2}{*}{ Guild } & \multicolumn{3}{c}{ Subdistrict } & Guild Composition \\
\cline { 3 - 5 } & & Gondomanan & Kraton & Ngampilan & \\
\hline 1. & Graminivorous & $45 \%$ & $51,30 \%$ & $43,44 \%$ & $46,58 \%$ \\
2. & Insectivorous & $49 \%$ & $41,45 \%$ & $49,08 \%$ & $46,51 \%$ \\
3. & Piscivorous & - & - & $0,88 \%$ & $0,29 \%$ \\
4. & Nectarivorous & $3 \%$ & $6,99 \%$ & $6,61 \%$ & $5,53 \%$ \\
5. & Frugivorous & $3 \%$ & $0,26 \%$ & - & $1,08 \%$ \\
\hline
\end{tabular}

Keterangan: A: tumbuhan banyak; B: tumbuhan sedang; C: tumbuhan sedikit.

\section{Species of birds which nested in the city of Yogyakarta}

Only 9 species of the bird species found in the city of Yogyakarta among 28 species are known to nest in this study at various places in the various wards. Pink-necked GreenPigeon (Treron vernans) and Large Big Green-Pigeon (Treron cappelei) were observed eating figs in the "Gedung Agung" (Figure 11) was later seen flying toward the west when it was getting dark. Common Kingfisher (Alcedo atthis) and Javan Kingfisher (Halcyon cyanovenris) were observed in the outskirts of Winongo although not known nest directly, but because it has a habit of his life to maintain territory then indirectly to be expected that they nest on the edge of Winongo (Figure 12).

Table 4: Species of birds which nested in the city of Yogyakarta

\begin{tabular}{|c|c|c|c|c|}
\hline \multirow[b]{2}{*}{ No } & \multicolumn{2}{|c|}{ Bird Species } & \multicolumn{2}{|c|}{ Nest } \\
\hline & English Name & Scientific Name & Site & Location \\
\hline 1 & $\begin{array}{l}\text { Pink-necked Green- } \\
\text { Pigeon }\end{array}$ & Treron vernans & $?$ & $?$ \\
\hline 2 & $\begin{array}{l}\text { Large Green-Pigeon } \\
\text { Besar }\end{array}$ & Treron cappelei & $?$ & $?$ \\
\hline 3 & Island Collard-Dove & Streptopelia bitorquata & In tall bayan trees & $\begin{array}{l}\text { Vill. Ngupasan and } \\
\text { Kadipaten }\end{array}$ \\
\hline 4 & Spotted-Dove & Streptopelia chinensis & In tall bayan trees & Vill. Ngupasan \\
\hline 5 & Emerlad Dove & Chalcophaps indica & $?$ & $?$ \\
\hline 6 & ZebraDove & Geopelia striata & $?$ & $?$ \\
\hline 7 & Glossy Swiftlet & Collocalia esculenta & $\begin{array}{l}\text { Under the bridges, building } \\
\text { and houses }\end{array}$ & $\begin{array}{l}\text { Vill. Ngupasan, } \\
\text { Ngampilan, Notoprajan, } \\
\text { Patehan dan Kadipaten }\end{array}$ \\
\hline 8 & Cave-Swiftlet & Collocalia linchi & $\begin{array}{l}\text { Under the bridges, building } \\
\text { and houses }\end{array}$ & $\begin{array}{l}\text { Vill. Ngupasan, } \\
\text { Ngampilan dan } \\
\text { Notoprajan }\end{array}$ \\
\hline 9 & $\begin{array}{l}\text { Sooty-headed } \\
\text { Bulbul }\end{array}$ & Pycnonotus aurigaster & $?$ & 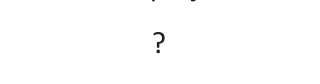 \\
\hline 10 & $\begin{array}{l}\text { Yellow-vented } \\
\text { Bulbul }\end{array}$ & Pycnonotus goiavier & $?$ & $?$ \\
\hline 11 & Ashy Tailorbird & Orthotomus ruficeps & $?$ & $?$ \\
\hline 12 & Common Tailorbird & Orthotomus sutorius & $?$ & $?$ \\
\hline 13 & Mountain Tailorbird & Orthotomus cucullatuss & $?$ & $?$ \\
\hline 14 & $\begin{array}{l}\text { Mueller'sBush } \\
\text { Wabler }\end{array}$ & Cettia vlcania & $?$ & $?$ \\
\hline
\end{tabular}




\begin{tabular}{|c|c|c|c|c|}
\hline \multirow[b]{2}{*}{ No } & \multicolumn{2}{|c|}{ Bird Species } & \multicolumn{2}{|c|}{ Nest } \\
\hline & English Name & Scientific Name & Site & Location \\
\hline 15 & Red-tailed Fantail & Rhipidura phoenicura & $?$ & $?$ \\
\hline 16 & $\begin{array}{l}\text { Brown-throated } \\
\text { Sunbird }\end{array}$ & Anthreptes malacensis & In Palmand coconut trees & $\begin{array}{l}\text { Vill. Ngupasan dan } \\
\text { Ngampilan }\end{array}$ \\
\hline 17 & Olive-backed Bird & Nectarinia jugularis & $?$ & $?$ \\
\hline 18 & Little Spiderhunter & Arachnothera longirostra & $?$ & $?$ \\
\hline 19 & $\begin{array}{l}\text { Scarlet-headed } \\
\text { Flowerpecker }\end{array}$ & Dicaeum trochileum & $?$ & $?$ \\
\hline 20 & Oriental White-eye & Zosterops palpebrosus & $?$ & $?$ \\
\hline 21 & Javan White-eye & Zosterops flavus & $?$ & $?$ \\
\hline 22 & Javan Munia & Lonchuraleuco gastroides & $\begin{array}{c}\text { In trees, small bayan rees and } \\
\text { palm trees }\end{array}$ & $\begin{array}{l}\text { Vill. Ngupasan, } \\
\text { Ngampilan, Notoprajan } \\
\text { dan Panembahan }\end{array}$ \\
\hline 23 & $\begin{array}{l}\text { Scaly-breasted M } \\
\text { unia }\end{array}$ & Lonchur apunctulata & $\begin{array}{c}\text { In trees, small bayan rees and } \\
\text { palm trees }\end{array}$ & $\begin{array}{l}\text { Vill. Prawirodirjan, } \\
\text { Ngampilan dan Patehan }\end{array}$ \\
\hline 24 & $\begin{array}{l}\text { White-headed } \\
\text { Munia }\end{array}$ & Lonchura maja & $\begin{array}{c}\text { In trees, small bayan rees and } \\
\text { palm trees }\end{array}$ & $\begin{array}{l}\text { Vill. Prawirodirjan dan } \\
\text { Notoprajan }\end{array}$ \\
\hline 25 & $\begin{array}{l}\text { Eurasian Tree } \\
\text { Sparrow }\end{array}$ & Passer montanus & $\begin{array}{l}\text { In houses and "genteng" } \\
\text { roofs }\end{array}$ & $\begin{array}{l}\text { Vill. Ngupasan, } \\
\text { Prawirodirjan, } \\
\text { Ngamilan dan } \\
\text { Notoprajan }\end{array}$ \\
\hline 26 & $\begin{array}{l}\text { White-vented } \\
\text { Myna }\end{array}$ & Acridotheres javanicus & $?$ & $?$ \\
\hline 27 & Common Kingfisher & Alcedo atthis & $?$ & $?$ \\
\hline 28 & Javan Kingfisher & Halcyon cyanovenris & $?$ & $?$ \\
\hline
\end{tabular}

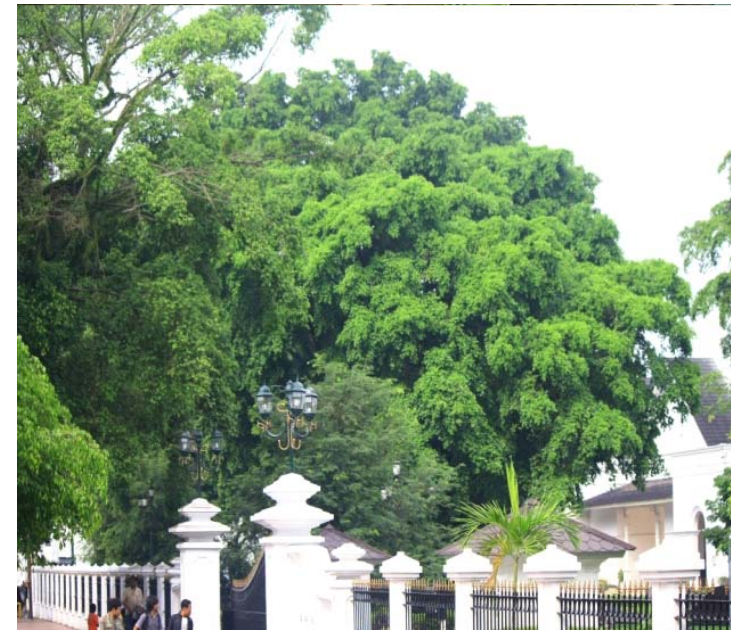

Figure 11: Big old bayan trees in the "Gedung Agung" (bu Surakhmat, 2013)

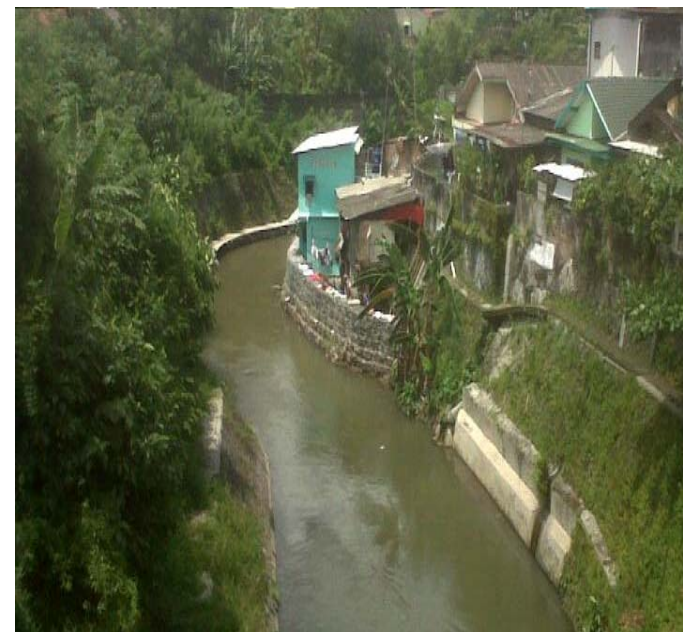

Figure 12: Winongo River in Subdisrict Ngampilan (by Sigit, 2013)

\section{CONCLUSION}

Yogyakarta City at least inhibited by 28 species of birds include 11 familia which diversity index moderate. Among of them 9 species are protected birds, most of them are graminivorous and insectivorous birds, and 9 species build nests in various sites and places in Yoyakarta City.

\section{REFFERENCES}

Bibby, C., J. Martin, and M. Stuart. 2000. Teknik-Teknik Ekspedisi Lapangan: Survei Burung. Birdlife Internasional Indonesia Progamme, Bogor. 
Hernowo, J.B., and L.B. Prasetyo. 1989. Konsepsi ruang terbuka hijau di kota sebagai pendukung pelestarian burung. Media Konservasi II(4): 61-71

MacKinnon, J., K. Philips, and B. Van Balen. 1991. Burung-burung di Sumatera, Jawa, Bali dan Kalimantan (termasuk sabah, Serawak dan Brunei Darussalam).Puslitbang Biologi-LIPI dan Birdlife International-Indonesian Programme, Bogor.

Odum, E.P. 1971. Fundamentals of Ecology. W.B. Saunders Company, Philadelphia. 574 pgs

Ontario, J., J.B. Hernowo, Haryanto, and Ekarelawan. 1990. Pola pembinaan habitat burung di kawasan pemukiman terutama di perkotaan. Media Konservasi III(1):15-28 